\title{
Quaternary environmental history of the Čejčské Lake (S. Moravia, Czech Republic)
}

\author{
EVA BŘízOVÁ
}

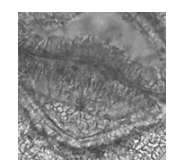

\begin{abstract}
The whole territory of Bohemia and Moravia with only two exceptions was located in the periglacial region during the Quaternary glacial periods. These exceptions were the northernmost part of Bohemia and the mouth of the Moravian Gate through which the continental glacier in the past penetrated this country and left traces in the form of moraines and in Moravia also sediments in the oldest Czech lake, Stonava. On the basis of pollen analysis, the organic sediments recovered there were dated to the Holsteinian Interglacial (Mindel/Riss). Natural lakes are rare in the Czech Republic (Černé, Čertovo, Prášilské, Plešné, Laka, Stonava, Komořany, Chrást, Stará Boleslav, Polabské černavy, Soos, Měňany, Švarcenberk, and Velanská cesta), since most of its territory has never been glaciated. As indicated by new palynological research, this statement does not fully apply to southern Moravia, where a number of lakes existed in the past, e.g. the former lakes Vracov, Čejčské, Kobylské, Vacenovice and Vlkoš. The deposition of lake sediments occurred mainly in the Holocene. According to the present research on the Čejčské Lake, the vegetation assemblages consist of species with various ecological requirements. Due to favorable circumstances, this site has been put forward for protection and designated a Natural Monument. - Key words: palynology, palaeoalgology, biostratigraphy, lakes, palaeoclimatology, palaeoenvironment, Quaternary, Late Glacial, Holocene, S. Moravia, Czech Republic.
\end{abstract}

BříZOVÁ, E. 2009. Quaternary environmental history of the Čejčské Lake (S. Moravia, Czech Republic). Bulletin of Geosciences 84(4), 637-652 (8 figures, 1 table). Czech Geological Survey, Prague. ISSN 1214-1119. Manuscript received April 27, 2009; accepted in revised form July 27, 2009; published online November 10, 2009; issued December 31,2009

Eva Bř́zová, Czech Geological Survey, Klárov 3/131, 11821 Prague 1, Czech Republic; eva.brizova@geology.cz.

During geological mapping of the Quaternary, carried out by the Czech Geological Survey in Prague, boreholes were drilled in the territory of Hodonín (on the map sheet, Čejkovice) in southern Moravia (Čtyroký et al. 1990). Some of them penetrated through the sediments of the former Čejské Lake fill, which represents a striking, predominantly tectonically limited depression (Havlíček \& Zeman 1979). The most complete profile through the youngest Quaternary sediments was obtained from borehole ČEJ 27 (the height of the terrain surface being about $175 \mathrm{~m}$ above sea level), in the center of the former lake. Sediments from this profile were used for the geological, palynological and palaeoalgological research, as well as for radiocarbon dating. The interpretation of palynological results presented here is based on experience from previous research carried out on other former and present lakes. The results have also served as source material for designation of the natural monument in the studied locality.

The Čejčské and Kobylské lakes are situated on the SE edge of the Ždánický les Hills, on the NW edge of the Dolnomoravský Valley between the villages of Kobylí, Brumovice and Čejč (Fig. 1). In subsequent years, other organic sediments, which are of interest from the botanical, ecological and geological point of view, were mapped and sampled from several other new localities in this area. They originated from wetland depressions in the forested area of wind-blown sands of the so-called Moravian Sahara (Doubrava). In these depressions, filled by sands blown from dunes, either organic sediments or impermeable Neogene clayey sands, silt and white, fine-grained sands were found (Břízová \& Havlíček 1999; Břízová et al. 2000, 2001a, b). It was therefore proved that the lakes originated in these depressions.

\section{Geological characteristics of the broader surroundings}

The territory in question lies in the Čejčsko-Zaječská zone (Fig. 1), which is an anticline strip in the internal part of the Ždánice unit of the Carpathian Flysch Belt in southern Moravia, situated between Nové Mlýny on the SW and Karlín on the NE. On the SE edge it is partly covered by Neogene sediments of the Vienna Basin, which penetrated as far as the transversal depression at Velké Pavlovice and 


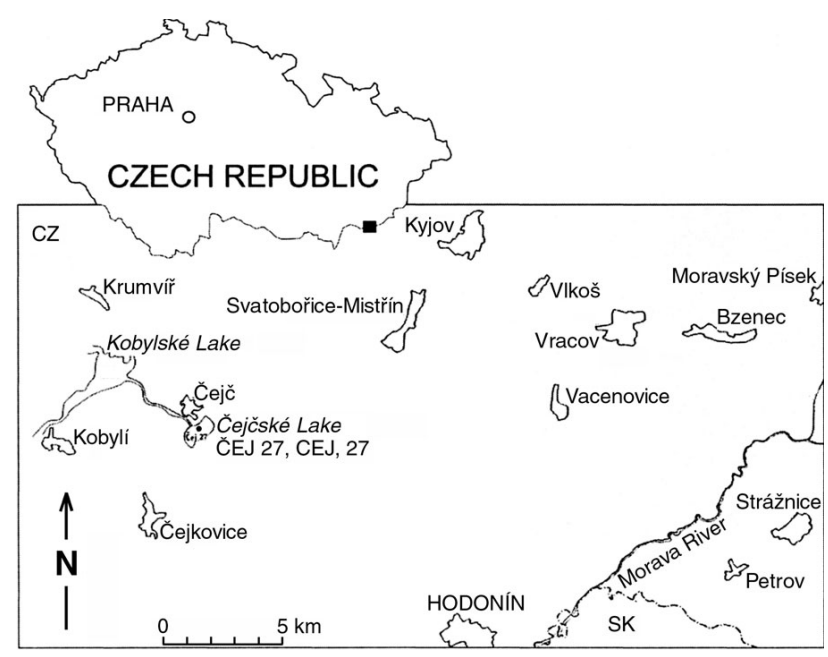

Figure 1. Map of the area surrounding Čejčské Lake, with locations of the lake localities in south Moravia discussed in the text.

Brumovice (Havlíček \& Zeman 1979). The Quaternary sediment research provided evidence that this area is rich in relatively strong solifluction and denudation effects so that in the surroundings of both depressions remains of the youngest loess only were preserved; regarding fluvial sediments, only the remains of the main terrace of Trkmanka and the gravel residue of a watercourse running in a NW to SE direction to Mutěnice have been traced. They were stratigraphically classified to the end of the Pliocene and the beginning of the Pleistocene. The axes of both valleys intersect perpendicularly.

The area of the Čejčské and Kobylské lakes was at the centre of interest for many scientists, even in the $19^{\text {th }}$ century; their analysis is reported in the paper by Havlíček \& Zeman (1979). Results of the latest research dealing with the Pre-Quaternary development of the Čejčsko-Zaječská zone, are described by Pícha et al. (1968).

The Quaternary sediments are represented by fluvial sediments of Trkmanka and the Čejčsko-Mutěnický watercourse, being deluvial and aeolic sediments. Ložek (1973) stated that in none of these depressions true limnic sediments have ever been found. This fact was also confirmed during the present study of borehole ČEJ 27. Pelíšek (1951) used the two lakes as an example of saline lakes and ponds which in the past dried out and their bottom used for agricultural purposes. This notion is fully corroborated by the present results of pollen analysis, which included corn and maize (Zea mays) pollen. Water of the Čejčské Lake had the highest content of salt. Therefore halophytes were preserved on the small surrounding areas (nature reserve) and in the territory of the former lake (Vicherek 1973, Grulich 1987); indeed, the subsequent pollen analysis proved the presence of halophyte pollen types belonging mainly to the families Chenopodiaceae, Asteraceae, Poaceae and Apiaceae.

\section{Čejčské Lake and its geological and historical development}

The Čejčské Lake is a vast, striking depression with an area of several square kilometres (Figs 1,2), along the perimeter it is limited by young fault slopes with the highest point being about $30 \mathrm{~m}$. The entire small basin is filled with Pannonian silt, clays and fine-grained Neogene sands. The Vienna basin is represented here by marine Pannonian fine-grained sands, silts and for the most part thinly stratified clays to claystones. On the NE and SE slope, the Kyjov lignite seam is outcropping, its age being more than 10 million years (Pannonian, zone B, see Fig. 2).

After a long gap in sedimentation lasting several million years, terrestrial sediments of Quaternary age were deposited, in particular during the last 2 million years. With respect to younger sediments, only Upper Holocene lacustrine clays and sands, and deluvio-fluvial sediments forming small outwash cones, are preserved. On the NW side near the lake, a layer of sandy loess developed but not reaching the bottom of the depression. The malacofauna recovered from the lacustrine sediments indicates the subrecent age of the gradually overgrown water reservoir (Kovanda, pers. com.). In the Quaternary the whole area was affected by frost, predominantly solifluction and denudation processes. Therefore in the close vicinity of the Čejčské Lake only pebbles from the Čejčsko-Mutěnický watercourse, blown by westerly winds can be found preserved in the top soil as well as much younger sandy loess. The start of deposition of the youngest Quaternary sediments in the Čejčské Lake during the Late Glacial and Holocene (the last 15,000 years), is corroborated by means of pollen analysis and radiocarbon dating of plant remains. The sedimentary fill began with green-grey and rusty spotted drifted clays with white carbonate precipitation on their surface. This represents runoff from the surrounding weathered Quaternary and Tertiary sediments, as was proved by the pollen analysis presented. After an interruption in sedimentation, humic clays and clayey loams were deposited, containing various salts leached from the underlying Pannonian sediments. The site was in reality a gradually overgrown water reservoir, as is corroborated by the malacofauna water species recovered, particularly from the upper part of the sediments of Čejčské Lake (Kovanda, pers. comm.). The study of crustaceans (Ostracoda) also proved the presence of saline waters in the lake. The species diversity of the Ostracoda assemblage increased slightly from the profile bottom upwards and culminated at the level 1.3-1.4 m under the ground surface. Above this level it slowly decreased; in the uppermost $20 \mathrm{~m}$, only one species, Heterocypris salina, occurred and finally also became extinct (Symonová 2002).

Natural draining of the lake probably proceeded in the direction of the present day drainage canal. The lake was 
artificially drained only after 1834 (see Fig. 3) by excavation of a canal leading towards the Trkmanka catchment area. The gradual uplift of the NW bank led to the construction of a pumping station at the beginning of the $20^{\text {th }}$ century, as drainage by gravity was not efficient. Nowadays, the height difference between the lake bottom and the drainage canal bottom is about $1.4 \mathrm{~m}$. Taking into account the very young lake fill and its relative thinness (1-3 m) and the lack of Pleistocene sediments, it seems probable that this situation arose during the Holocene (Havlíček $\&$ Zeman 1979). At the beginning of the $20^{\text {th }}$ century, the centre of the Čejčské Lake was repeatedly flooded and waters from the lake again had to be pumped to the drainage canal leading to the Trkmanka valley near Terezín.

The Čejčské Lake was one of many lakes in southern Moravia which originated after the end of the last glacial period. As it is generally accepted, it developed within an old settlement area that was probably first inhabited by Palaeolithic Man (Aurignacian). In the Neolithic, the settlement was poorly inhabited and the population did not increase again until the Bronze and Iron Ages. This landscape was populated by the Germans and the Slavs. Deforestation of hills had taken place since the earliest historic times and perhaps even in the prehistoric times. Today forests are spread only on ridges of the Ždánický les Hills and to a small extent, west of Klobouky and Kobylí. The remaining territory is used as fields, orchards and vineyards. Quick siltation of the former system of the Čejčské and Kobylské lakes and ponds by sludge took place mainly between the $15^{\text {th }}$ to $18^{\text {th }}$ centuries and for this reason the waters in this area dried up during the $18^{\text {th }}$ and $19^{\text {th }}$ centuries. The pace of siltation was also connected with lithology, because the underlying rocks represent slightly compacted sandy silts. Thus wetlands and marshlands secondarily developed in former dry places (Havlíček \& Zeman 1979).

\section{Methods and aims of palaeobotanical reaserch}

From the borehole ČEJ 27, situated in the lake centre (Čtyroký et al. 1990), about 2 m of sediments of assumed Quaternary age were sampled for pollen analysis. Although the sediment was not very promising for palynological evaluation carried out in the following years, it became apparent that this study would be important both for the verification of mapping results and for the needs of environmental research and monitoring of the Quaternary climatic changes. From these two-meters, consisting of organic and inorganic sediments, 40 samples were obtained (sampling was selected to be as detailed as possible in order to characterize individual beds). The samples were treated using the current technique used for separation of sporomorphs:

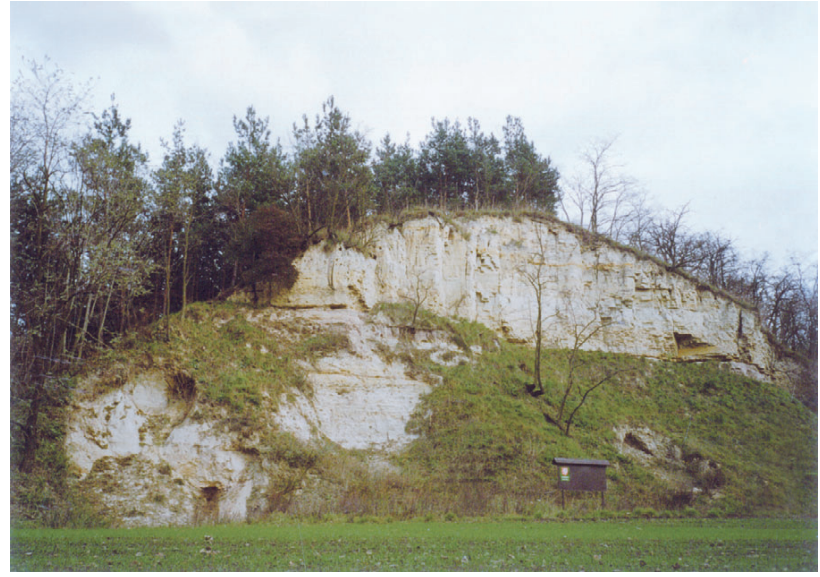

Figure 2. Former shore of Čejčské Lake: outcrop of Pannonian clays, silts and sands. On the left, an outcrop of the Kyjov lignite seam (Pannon, zone B). Photo by E. Břízová.

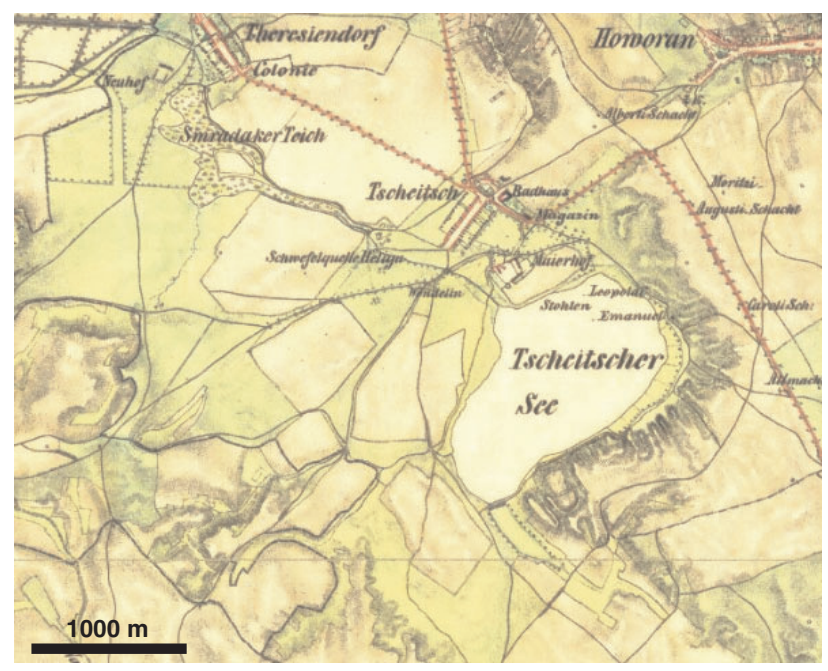

Figure 3. Historical map (1836-1852) proving the existence of the Čejčské Lake. (C) $2^{\text {nd }}$ Military Survey, Section No. O_12_III, Austrian State Archive/Military Archive, Vienna, (C) Laboratoř geoinformatiky Univerzita J.E. Purkyně - http://www.geolab.cz, (C) Ministerstvo životního prostředí ČR - http://www.env.cz.

1) maceration in HF for about 24 hours; 2) Erdtman acetolysis (Erdtman 1943, 1954); 3) the obtained solution of sporomorphs were preserved in a mixture of glycerolethanol and distilled water at a suitable ratio. Simultaneously with sampling for pollen analysis, one sample was taken for radiocarbon dating of organic sediments (CEJ $27-1 / 2-2.2 \mathrm{~m})$ carried out at a laboratory in Hannover $\left({ }^{14} \mathrm{C}\right.$ und ${ }^{3} \mathrm{H}$-Laboratorium, Niedersächsisches Landesamt für Bodenforschung, Hannover; Hv-18 924).

Counting of the pollen grains, spores and other microscopic remains was carried out under a cover glass of $22 \mathrm{~mm}$ by $22 \mathrm{~mm}$ in size. The raw data are given in the attached Table 1 (see online version of the paper on www.geology.cz/bulletin/contents) and percentages are in 


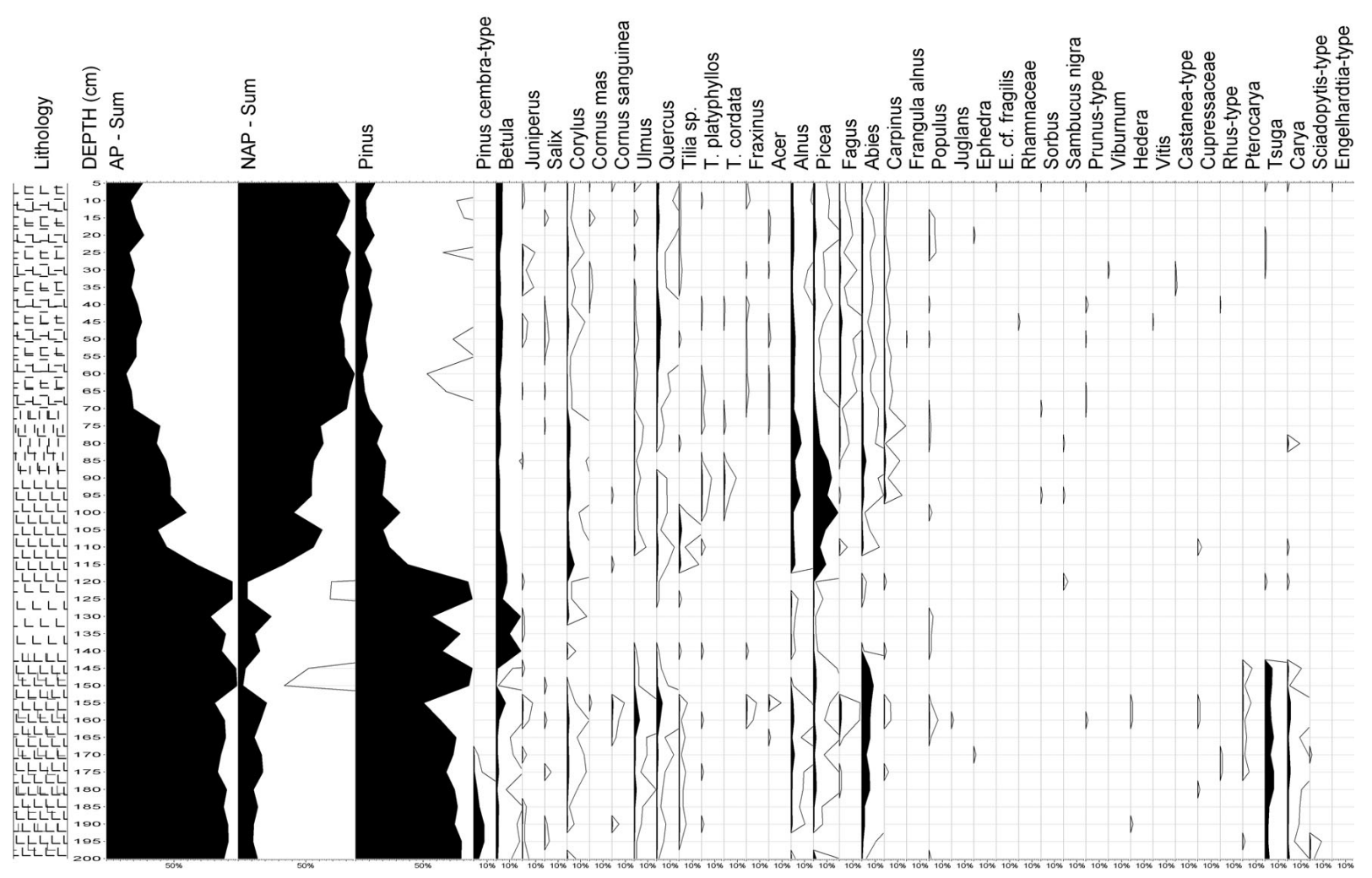

Figure 4. Pollen diagram from the locality of Čejčské Lake (ČEJ 27).

the pollen diagram (Fig. 4). The diagram was plotted by means of the program POLPAL (Walanus \& Nalepka 1999). The number of pollen grains of woody species (AP) varies from 350 to 500 (some samples contained a very small amount of pollen and it was necessary to use up to 7 microscopic preparations). The basic sum (100\%) being a total of AP plus terrestrial herbaceous plant pollen (NAP). Spores and other remains (also animal) are calculated in the relation to the basic sum.

The stratigraphic position was derived from the Firbas classification of vegetation development in Central Europe (Firbas 1949, 1952), used for evaluation of palynological spectra in our territory and modified on the basis of palynological experience of the author (Břízová in Dreslerová et al. 2004) and Mangerud et al. (1974). The local pollen assemblage zones (L PAZ) were identified and their stratigraphic position, necessary for the needs of geological mapping and territory development, was determined. The determination of palynonomorphs was carried out with the aid of a reference collection and according to pollen keys. The algal flora was evaluated according to the research by Jankovská and Komárek (Jankovská \& Komárek 2000, Komárek \& Jankovská 2001) and other illustrations published in the work of various authors.

\section{Natural lakes in Bohemia and Moravia}

Almost the whole part of the territory of Bohemia and Moravia was laid down during the Quaternary Glacial period in the periglacial area. The exception is the mouth of the Moravská Gate, through which the continental glacier penetrated in the past leaving traces in the form of moraines and sediments in the former Stonava Lake (Břizová 1994; Kneblová 1958a, b; Kneblová-Vodičková 1961; Macoun et al. 1965). On the basis of pollen analysis the age of the recovered organic sediments was determined to be Holsteinian interglacial (Mindel/Riss).

Only the highest mountains were covered by mountain glaciers, but not all the lakes in these mountains persisted until the present time. Therefore, a part of glacier cirques in the Šumava and Krkonoše Mts are smaller mountain lakes (some of them are almost silted up - e.g. Laka in the Šumava Mts, others are still lakes e.g. the Černé Lake (Břízová 1991a, b, 1993, 1995, 1996; Jankovská 2000), the Čertovo Lake (Břízová 1996), the Prášilské Lake (Břízová 1999, 2000; Břízová in Hruška et al. 1999, Hruška et al. 2000), the Plešné Lake (Jankovská 2006), and in Bavaria, the Great and Small Javorské lakes, the Rachel Lake and the mountain lakes in the Krkonoše Mts, e.g. the Wiełki Staw Lake - 

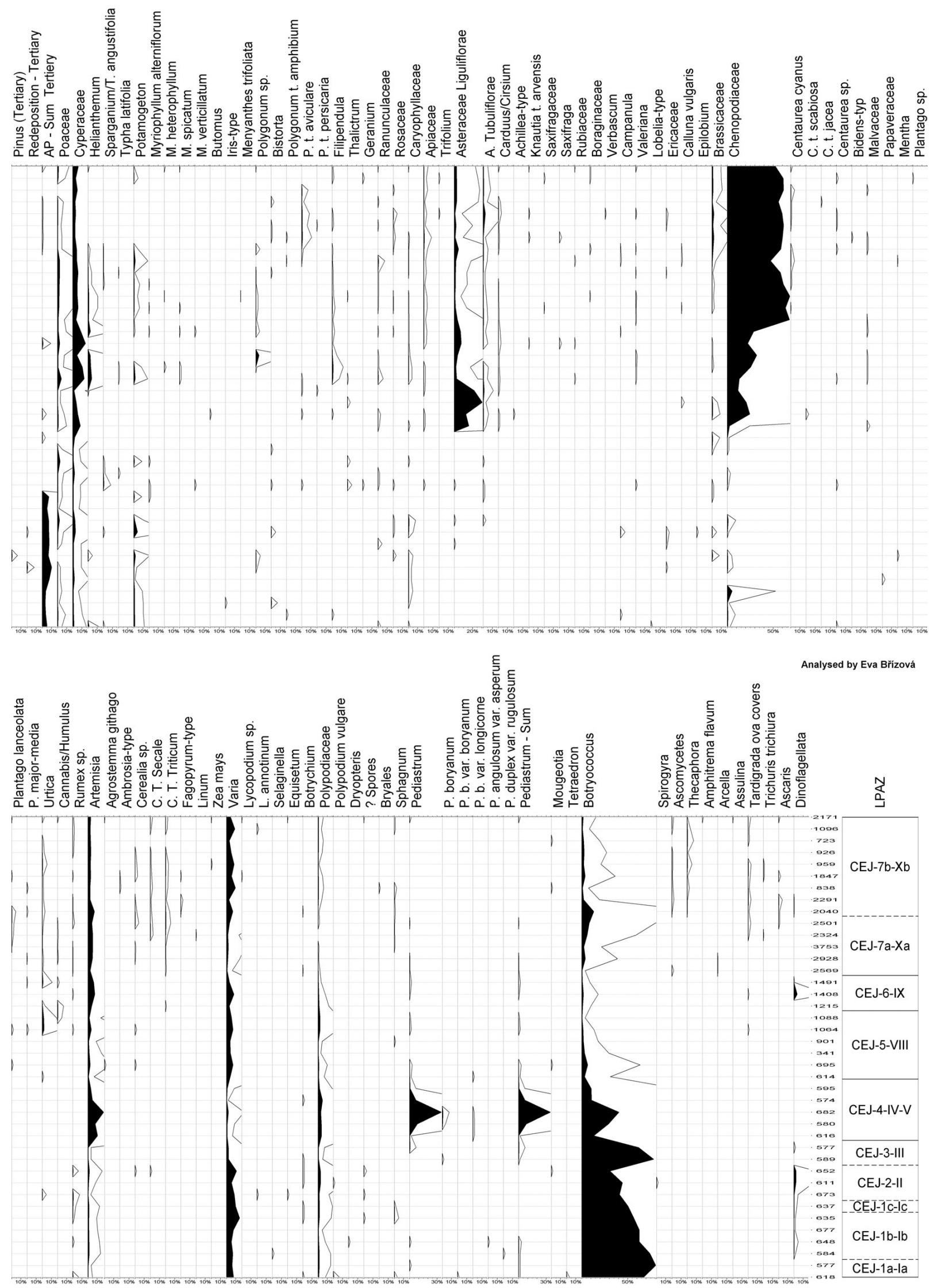
situated on the Polish side (Břízová 1999, Břízová in Hruška et al. 1999, Hruška \& Břízová 2007). Silted lakes have recently been found in the Šumava Mts (the Stará jímka Lake; Břízová 2008; Bř́zová et al. 2006, 2007a, b) and in the Krkonoše Mts in the Labský Valley (Jankovská 2007).

Undoubtedly, the largest natural lake in our territory was the Komořany Lake in the Most Basin in NW Bohemia (Jankovská 1983, 1988, 2000). It originated due to tectonic movements in synergy with sedimentation of wind-blown sands, which dammed up a watercourse of the Bílina River. It was a water reservoir of about 1,200 ha in its original area. Even as late as the end of the last century, its remains represented a dominant part of landscape in the Podkrušnohoří area and probably considerably affected the climate of the Most Basin and the adjacent Krušné hory Mts.

In the majority of Bohemia and Moravia, which was never covered by ice, original lakes are rare, if we do not take into consideration small reservoirs in river floodplains with usually short term persistence - oxbow lakes or small lakes created, for example, by beaver activities. If the sediments of oxbow lakes are considered as an example of former small lakes, the first to be analyzed in our territory were those of the Labe River (Chrást, Stará Boleslav Břízová 1995, 1996, 1997, 1999a, b).

In the Třeboň Basin, in addition to the Švarcenberk Lake (Jankovská 1980, 1983, 2000), one small extinct lake was recovered on the border with Austria - Velanská cesta Lake (Jankovská 1983). Not much is known about its origin. The same applies to another former lake in the area of the present Soos reservation near Františkovy Lázně, where only dia-

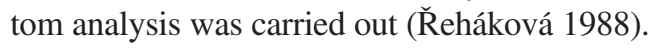

Other lakes, in most cases also smaller sized, originated either in the karst regions by accumulation of water in front of travertine cascades, e.g. the former Měnany Lake in the Bohemian Karst (Dohnal et al. 1965; Kovanda 1956, 1971), or by impact of airborne sands in the Late Glacial which dammed up a water course or the mouth of a spring, e.g. Polabské černavy Mollisols - Hrabanovská černava Mollisol (Pacltová \& Hubená 1994) or the former lake Vracov in southern Moravia (Rybníček 1983, 1989; Rybníčková 1985; Rybníčková \& Rybníček 1972; Svobodová 1989, 1997).

The Čejčské and Kobylské lakes are today morphologically striking depressions, which, according to Havlíček \& Zeman (1979), originated in the youngest period of the Middle and Upper Holocene. Their origin is connected with rejuvenation of tectonic activity of transverse fractures, parallel to a depression in the Nesvačily trench.

During the later Quaternary geological mapping in the Hodonín area, sediments from several other localities were found and sampled and after detailed palynological-palaeoalgological research, two of them were determined as remains of former small lakes, Vacenovice and Vlkoš (Břízová \& Havlíček 1999). The locality, which is recorded as Vacenovice, is known in maps under the name of Jezero (Lake). Both former lakes are situated in the vicinity of the Vracov Lake. However, the sequence of their sediments includes the Holocene with distinct gaps (with an incoherent sequence of stratigraphically classifiable strata). Compared with Vracov, the lake at Vacenovice might have been silted up at the end of the Preboreal. As the whole sequence of sediments was not preserved, age cannot be determined precisely.

At the onset of the Late Glacial, sedimentation of organic material started in lakes which developed in depressions among dunes and deposition continued also during the following Holocene. An example could be the lake extending westwards from Vracov and $20 \mathrm{~km}$ northward of Mikulčice, at an altitude of about $190 \mathrm{~m}$. Its profile, documented by a borehole, was examined from the geological, palynological and geochronological point of view. After comparing the results of radiocarbon dating and the pollen spectrum, it was found that sedimentation was not straightforward (Rybníčková \& Rybníček 1972). At the profile base, there are clay and sand beds, on which gyttja (algal) is gradually deposited and towards the surface, beds of gyttja and sedge, reed, and sedge-reed fen alternate. The lake probably existed until the end of the Preboreal, as evidenced by the presence of algal gyttja. During the Boreal and the Atlantic, the edges of the lake were overgrown thus forming thus typical sedge-reed fen beds. In the younger Subatlantic, marshland became dry and was used as field, but probably often flooded. The other South Moravian lakes, Čejčské and Kobylské, were similarly affected. To sum up it can be stated that Neolithic agricultural activity started at about 6,500 B.P. with slow deforestation and corn cropping. The beginning of intensive farming was dated around 3,000-2,500 B.P. Maximal deforestation of the territory began between 1,500-1,000 B.P. during the migration of nations and arrival of Slavs.

\section{Description of sediments in the Čejčské Lake}

The locality of the Čejčské Lake (ČEJ 27) is situated about $175 \mathrm{~m}$ above sea level, south of the South Moravian village Čejč, north of Čejkovice (see Figs 1,3) and 10 km NW of Hodonín. It is situated $10 \mathrm{~km}$ west of the former Vacenovice Lake at Vacenovice (see Fig. 1).

Figure 5. Sporomorphs from the Čejčské Lake ČEJ 27 - AP. • A, B - Abies, sample 4, depth 0.20 m. • C, D - Quercus, sample 10 , depth 0.50 m. • E - Betula, sample 4, depth $0.20 \mathrm{~m}$. F, G - Pinus, sample 39, depth $1.95 \mathrm{~m}$. $・$ H, I - Tsuga, sample 39, depth $1.95 \mathrm{~m}$. • J, K - Fagus, sample 10, depth $0.50 \mathrm{~m}$. $・ \mathrm{~L}, \mathrm{M}-$ Quercus, sample 10, depth $0.50 \mathrm{~m}$. $・ \mathrm{~N}, \mathrm{O}-$ Alnus, sample 10, depth $0.50 \mathrm{~m}$. Photo E. Břízová. 
Eva Bř́zová • Quaternary environmental history of the Čejčské Lake (Moravia)
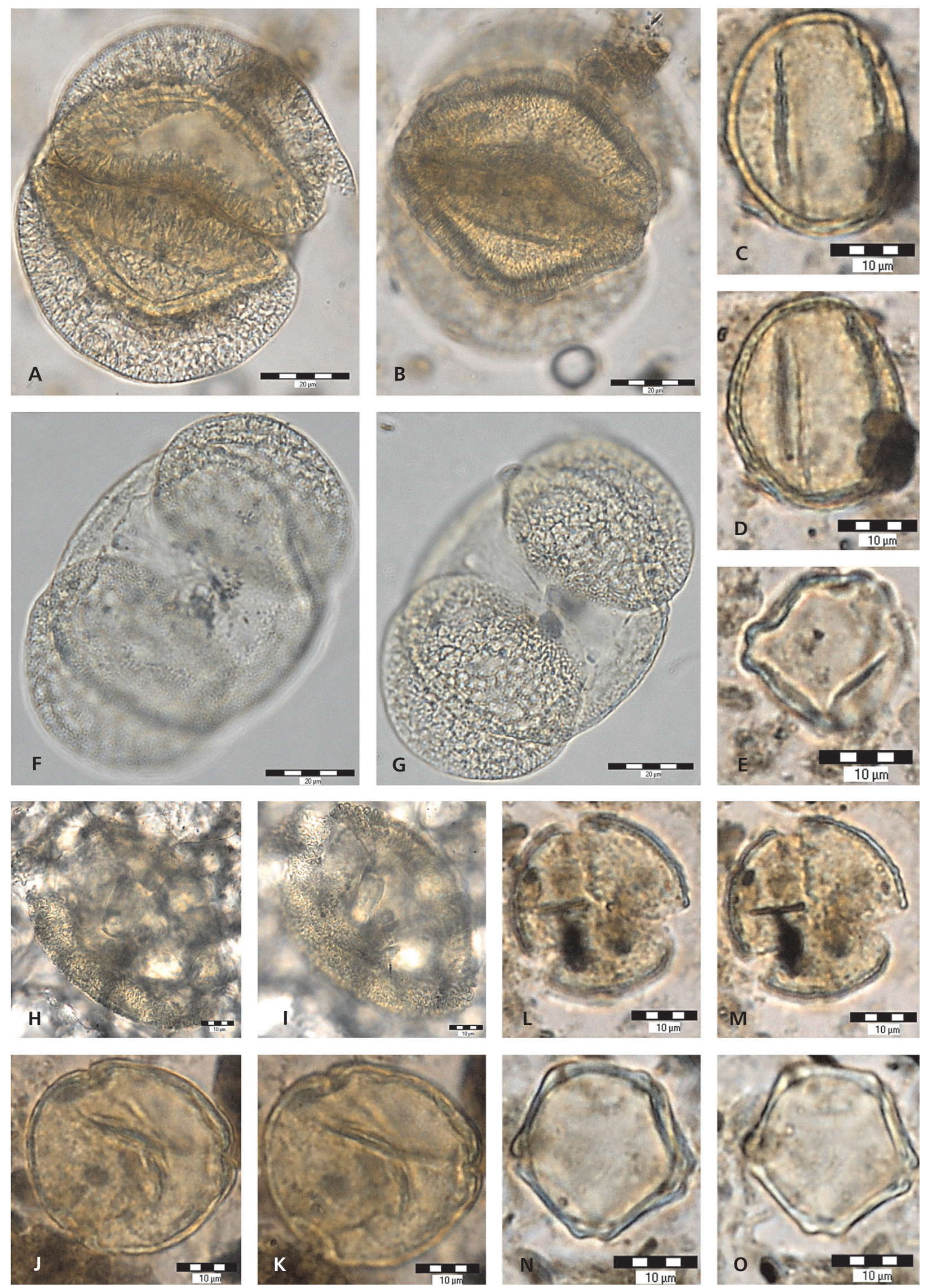
Each sediment layer was considered during sampling of the core.

\section{Lithostratigraphy}

Quaternary

0-0.7 m: medium brown-black, humous loam,

$0.7-0.9 \mathrm{~m}$ : black strongly humous loam with peat remains,

0.9-1.2 m: grey-brown, strongly clayey loam,

1.2-1.4 m: white, clayey horizon, strongly enriched with $\mathrm{CaCO}_{3}$ (hiatus?),

1.4-2 m: green-grey and yellow-rusty, streaky and spotted clay.

Palynologically unanalyzed Tertiary sediment was found under the Quaternary sediments.

Tertiary

2-6 m: steel-grey clay, at the depth of 4-6 m, thinly stratified, with brown positions (redeposited?).

The raw pollen data are shown in Table 1. It is accompanied by pollen diagrams (Fig. 4) showing the reconstruction of natural habitat development in detail together with L PAZ (local pollen assemblage zones) and biostratigraphical development.

\section{Local pollen assemblage zones}

\author{
CEJ-1a-Ia: Pinus - P. cembra \\ CEJ-1b-Ib: Pinus - P. cembra - Chenopodiaceae \\ CEJ-1c-Ic: Pinus \\ CEJ-2-II: Pinus - Betula-Populus - Potamogeton-Abies \\ CEJ-3-III: Pinus
}

Stratigraphic and palaeovegetational interpretation of the pollen spectra from the depth interval $1.45-2 \mathrm{~m}$ is difficult due to the redeposited Tertiary sporomorphs. The radiocarbon age of its base (give the exact depth of the ${ }^{14} \mathrm{C}$ sample) is $9,990 \pm 275$ years B.P. (Calibrated age range: $68 \%$ 10,118-9,226 BC, 92.5\% 10,459 - 8,787 BC; Hv-18 924), which corresponds to the onset of the Preboreal. Unfortunately, the charcoal macro-remains dated, were most probably not found in the in-situ position. This complicated situation was due to runoff from the surrounding Tertiary deposits during the Holocene and Late Glacial periods (15,000/13,000-10,250 B.P.), when the vegetation cover was not completely involved and a considerable part of mostly inorganic material was transported and deposited in the lake. This is also verified by the character of the sediment sampled (see the Description of sediments section). The Tertiary redeposition of sporomorphs can be substantiated by the number of pollen grains from woody species (see pollen diagram, Figs 4, 5), which are solely Tertiary elements: e.g. sporomorphs belonging to Cupressaceae, Tsuga, Carya, Sciadopytis-type. Some of them e.g. Pterocarya also occurred in the Pleistocene. Dinoflagellata are present throughout the described layer, which is always evidence of re-deposition of palynomorphs from older strata. On one hand, pollen grains of plants growing in the Late Glacial or the Early Holocene, e.g. Pinus cembra-type, Juniperus, Salix, herbaceous Helianthemum, spores of Selaginella $\mathrm{cf}$. selaginoides, Ephedra, typical of mostly colder conditions, have been recovered from undisturbed vegetation cover and on immature soils. On the contrary, other assemblages of palynomorphs characterize a climatically less hardy part of the pollen spectrum, as corroborated by the presence of pollen grains of e.g. Corylus, Ulmus, Quercus, Tilia, Picea, Abies, Fagus, Carpinus, Hedera. These might have been re-deposited from either the Pleistocene or Middle Holocene sediments during borehole sampling. However, the probability of preservation of the Pleistocene sporomorphs, is from the geological research point of view (Havlíček \& Zeman 1979) almost out of the question, but its former presence is confirmed by the pollen spectrum. The total sum of woody species pollen grains (apart from re-deposited taxa) prevails over herbs in the whole bed, mostly probably due to the presence of pine (Pinus) which has heavy pollen production. However, the presence of a forest is not guaranteed by this. It probably reflects rare pine stands of park character, as at the same time, a number of heliophytes were found in the same samples. At the depth of $1.55 \mathrm{~m}$, herb types, which are connected with man, e.g. corn (Cerealia type, C. Type Secale), occur. Here it is probably contamination. A higher amount of Chenopodiaceae and Rumex pollen represents halophyte vegetation. Areas of free water throughout the stratum are indicated by Potamogeton. An increased amount of Juniperus, Rumex and Urtica pollen grains in some samples might also be a consequence of the are being formerly pasture.

The stratigraphic classification of the whole bed is considerably problematic and indeterminable precisely. Late Glacial and Early Holocene (Lower Holocene) sedimentation is recognizable with re-deposition from Tertiary, Pleistocene and Middle Holocene strata. On the basis of its geological position and vegetation development, the Late Glacial stratum was segmented according to the Firbas' scheme into the Oldest Dryas (Ia), interstadial Bölling (Ib), the Older Dryas (Ic), interstadial Alleröd (II) and the Younger Dryas (III); the Dryas period was colder than both the interstadials.

\section{CEJ-4-IV-V: Pinus - Betula - Artemisia}

The second bed (depth 1.2-1.45 m). In the lower part there is a continuous occurrence of some woody species, e.g. 

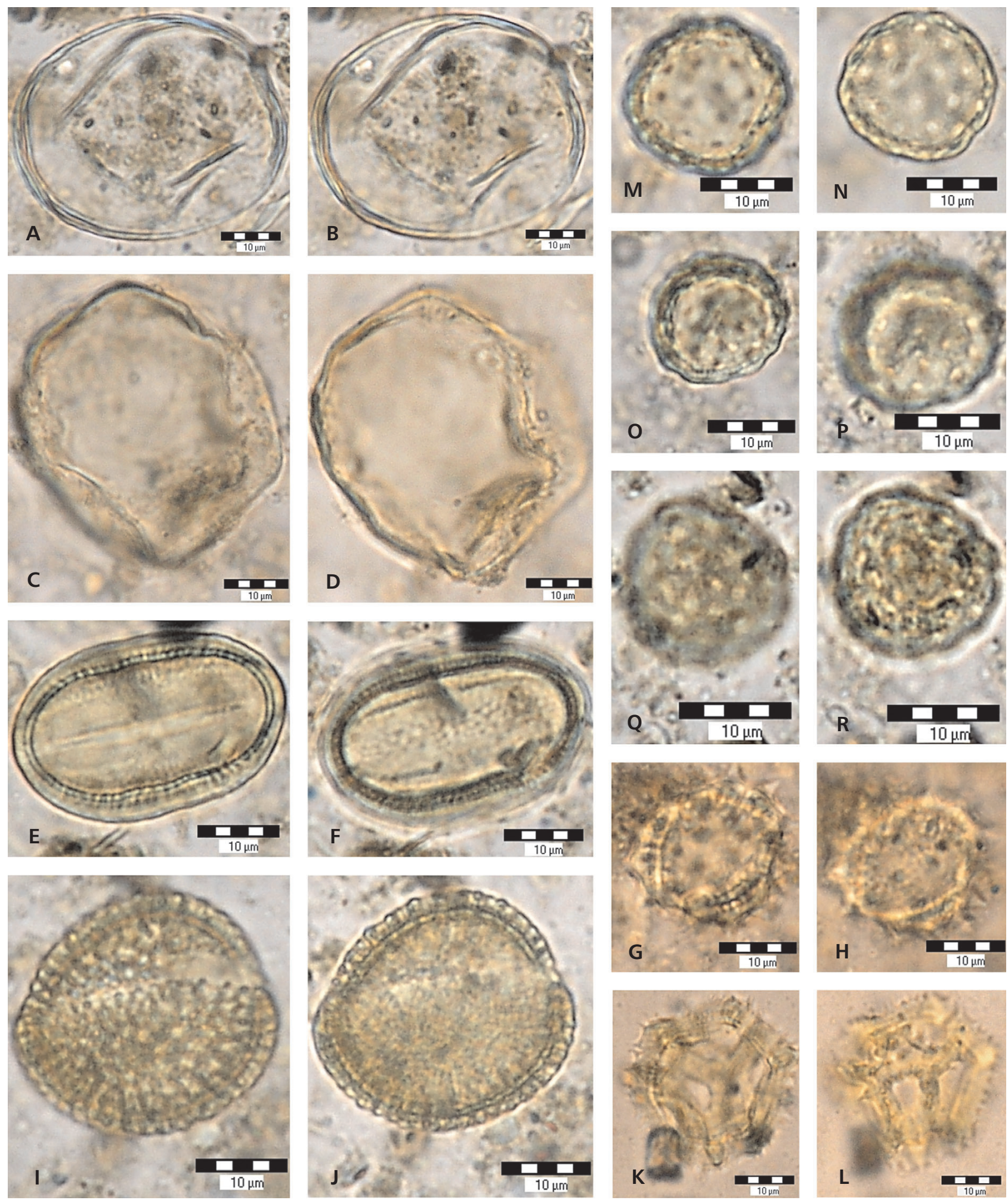

Figure 6. Sporomorphs from the Čejčské Lake ČEJ 27 - NAP. • A, B - Cerealia T. Triticum, sample 10, depth 0.50 m. • C, D - Cyperaceae, sample 4, depth $0.20 \mathrm{~m} \cdot \bullet \mathrm{E}, \mathrm{F}-$ Centaurea cyanus, sample 10, depth $0.50 \mathrm{~m} \cdot \bullet \mathrm{G}, \mathrm{H}-$ Asteraceae Tubuliflorae, sample 5 , depth $0.25 \mathrm{~m}$. $\bullet$ I, J - Brassicaceae, sample 10, depth $0.50 \mathrm{~m} \cdot \bullet \mathrm{K}, \mathrm{L}-$ Asteraceae Liguliflorae, sample 20, depth $1.00 \mathrm{~m}$. $\bullet \mathrm{M}-\mathrm{R}$ - Chenopodiaceae, sample 4, depth $0.20 \mathrm{~m}$. Photo E. Bř́izová. 

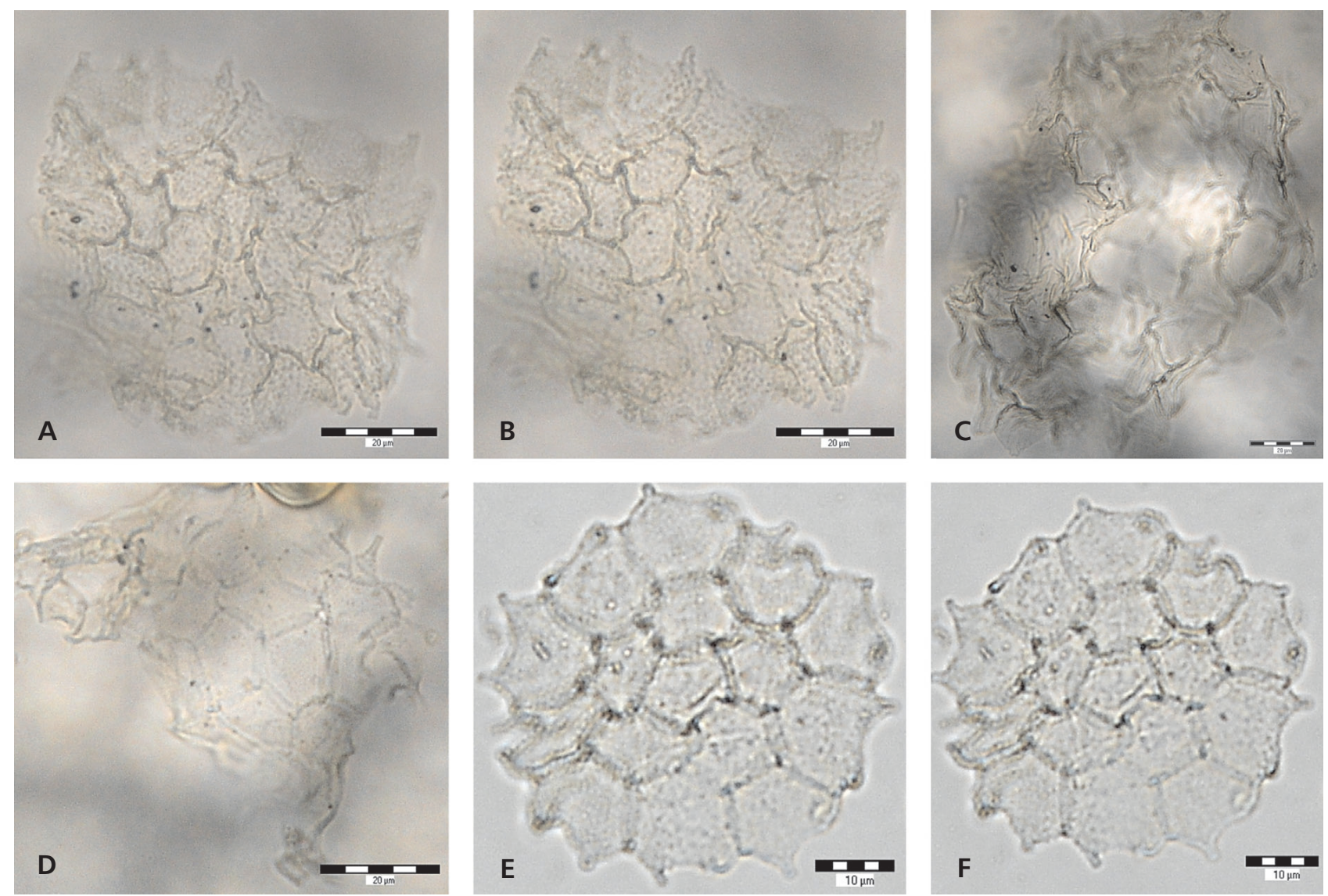

Figure 7. Algae from the Čejčské Lake ČEJ 27. • A, B - Pediastrum boryanum var. boryanum, sample 39, depth 1.95 m. • C - Pediastrum sp., sample 39, depth 1.95 m. • D - Pediastrum sp., sample 39, depth 1.95 m. • E, F - Pediastrum boryanum s.l., sample 39, depth 1.95 m. Photo E. Břízová. Determination by V. Jankovská.

Ulmus, Quercus, Tilia, Abies, Carpinus, but re-deposition of Tertiary woody species (with exception of the uppermost sample from this layer) ceased. The amount of birch pollen (Betula) increased. The amount of wormwood pollen (Artemisia) greatly increased and also diversity of herbaceous types. The layer is, in comparison with the previous one, without a strong mineral admixture.

A considerable amount of pine pollen (Pinus) was again found, however without cembra pine (Pinus cembra-type). On the basis of the recovered plant spectrum we can say that the stratum represents the Preboreal and the onset of the Boreal, probably lacking elements from part of the Middle Holocene. A hiatus in sedimentation was also revealed geologically. In the Atlantic, when the involvement of vegetation was generally higher, limited runoff from the surrounding beds probably took place, and therefore the sediments of this period were not preserved due to erosion. On the contrary, at the boundary of the Boreal and the Atlantic, lesser involvement of vegetation cover lead to more massive denudation of sediments. A similar situation was recorded in the Vacenovice Lake (Bř́zová 2001a) and other localities (see Rybníček 1989).
CEJ-5-VIII: Picea - Pinus - Asteraceae Liguliflorae Chenopodiaceae - Cyperaceae - Helianthemum

This bed, at the depth of 0.9-1.2 m, contains clayey loam. Sporomorph concentration was very low. Overgrowth and siltation of the reservoir, the drier Subboreal climate and the increased salinity of the lake water probably became important. This idea could also be supported by the gradual disappearance of the majority of wetland and marshland herbaceous taxa compared with the previous bed (Sparganium/Typha angustifolia, T. latifolia, Potamogeton, Bistorta). The presence of halophyte vegetation is confirmed by the large amount of pollen grains of Chenopodiaceae, Asteraceae Liguliflorae, A. Tubuliflorae, Poaceae, Apiaceae, and Cyperaceae (Fig. 6). Concurrently, the presence of man can also be identified by a certain amount of Asteraceae Liguliflorae and sporadic occurrence of Agrostemma githago and Cerealia pollen. For the first time in the analyzed material, the woody plant component quite considerably declines, while the herbaceous cover increased (see Table 1 and pollen diagram, Fig. 4). The maximum occurrence of spruce pollen (Picea) reaches about $20 \%$. If we compare the situation with some pollen spectra from other 
localities of southern Moravia, the amount of pollen grain averages about $10 \%$ and culmination of this taxon shifts to a later time, depending on how far westward the locality is situated with respect to the Čejčské Lake (Vracov VI, VII to VIII; Svatobořice-Mistřín VII-VIII; Anšov in the half of VIII to IX; Olbramovice Xb). This result corroborates the opinions of Rybníčková (1985). As opposed to spruce (Picea), a remarkable decrease in representation of pine pollen grains (Pinus) occured but fir (Abies), beech (Fagus), hornbeam (Carpinus), oak (Quercus) and elm (Ulmus) appeared. During the entire period linden (Tilia sp., T. platyphyllos, T. cordata) also became more markedly represented. Sediments were probably deposited in the Subboreal (VIII) but with the influence of sediments from the Atlantic or the Older Subatlantic.

\section{CEJ-6-IX: Pinus -Alnus - Cyperaceae-Chenopodiaceae}

The layer at the depth of $0.7-0.9 \mathrm{~m}$ contained a higher amount of organic material. It was deposited in the Older Subatlantic (IX). The perceptible drop in the woody pollen content (AP) is connected with initial deforestation in this area. Regarding herbs, Artemisia (wormwood) and Asteraceae pollen increased, and also, as in the previous bed, the Chenopodiaceae increased. Sporadically, corn also (Cerealia) appeared. The increasing amount of alder pollen (Alnus) and pollen of the Cyperaceae (sedge family) indicates a climate with increased humidity. This period is recorded only in a thin layer of deposited sediments.

CEJ-7a-Xa: Chenopodiaceae-Pinus - Quercus - Cerealia CEJ-7b-Xb: Chenopodiaceae - Pinus - Asteraceae Brassicaceae

The uppermost bed, at 0-0.7 m, was deposited in the Younger Subatlantic (X). On the basis of vegetation development, it can be divided into an older phase (Xa) at $0.45-0.70 \mathrm{~m}$ and a younger phase $(\mathrm{Xb})$ at $0-0.45 \mathrm{~m}$. It is characterized by a more extensive occurrence of elements indicating man's activity, including herbs such as Centaurea cyanus (cornflower), Cerealia (corn), Urtica (nettle), Rumex (sorrel), Artemisia (wormwood) and some types of the Chenopodiaceae. Pollen from the Chenopodiaceae, Asteraceae Liguliflorae, A. Tubuliflorae, Brassicaceae, Apiaceae, Cyperaceae and Poaceae most probably reflect the local halophyte flora. Noteworthy is the findings of parasitic worm eggs cases of Trichuris trichiura as well as Ascaris cf. lumbricoides (pin worm), which can be found mainly in buildings from the Middle Ages. From woody species which became significant in this layer, pine (Pinus) was more markedly represented followed by birch (Betula) as well as alder (Alnus). The representation of other types, such as hazel (Corylus), oaks
(Quercus), lindens (Tilia), maples (Acer), spruce (Picea), beech (Fagus), fir (Abies) and hornbeam (Carpinus) was negligible. Mostly in the younger phase $(\mathrm{Xb})$, re-deposition of predominantly Tertiary types, which had been transported down to the lake from the surrounding Tertiary outcrops, reappeared in the pollen spectrum. In the upper sample and in $0.25 \mathrm{~cm}$, maize pollen grains (Zea mays) were found. Cultivation of this agricultural crop-plant in our country to a large extent began in the seventies of the $20^{\text {th }}$ century. Deposition of these sediments was relatively recent and was verified by highly allergenic type of Ambrosia, which spread to our territory only recently. Probably, the lake had already dried out by the time of bed $\mathrm{Xb}$.

\section{Halophytes}

Halophytes are herbs growing in soils saturated with salts. Because there are no salty soils (salty steppes) in the area under study, their occurrence is climatically controlled and these plants are a good indicator of edaphic conditions. Rare occurrences of such soils are of soligenic origin, i.e. controlled by the chemistry of the bedrock, the effect is usually strengthened by a drier climate, physical properties of the soils (clays) and the relief (Sýkora 1959). Soil salinity is usually effected by sulphates extracted from the surrounding clayey-marly layers; they are mostly sulphate, alkaline soils with an admixture of chlorides. A certain aggressiveness of the environment is proved by the very poor preservation of pollen grains and spores, and corrosion of their surfaces.

The physiognomy of salty soil development creates the wetland to marshland character, with a relatively high content of ruderals (nitrophytes).

The typical South Moravian halophytes are Salicornia prostrata and Suaeda pannonica (both from the Chenopodiaceae). Other types include Bupleurum tenuissimum (Apiaceae), Cirsium brachycephalum (Asteraceae Tubuliflorae), Galatella cana, Scorzonera parviflora, Taraxacum bessarabicum, Tripolium pannonicum (all Asteraceae Liguliflorae), Crypsis aculeata, Heleochloa schoenoides (both Poaceae), Plantago maritima (Plantaginaceae), Spergularia marina, S. maritima (Dianthales), Glaux maritima, Samolus valerandi (both Primulaceae), Triglochin maritimum (Juncaginaceae) and probably Veronica scardica (Scrophulariaceae). In the surroundings of Čejč, until recently there was salt marsh and the halophytes which grew there are also recorded in the pollen diagrams, where they consistute a part of the pollen profiles of the families Chenopodiaceae, Apiaceae, Poaceae, Caryophyllaceae, Asteraceae Tubuliflorae and Liguliflorae and Plantago sp. There was one small natural reserve, but not very many halophytes have been growing there recently. Genuine halophilous vegetation became extinct during the sixties of the $20^{\text {th }}$ century (Grulich 1987, Šumberová et al. 2004). The existence of salt 
marsh depended on the presence of salty Tertiary sediments, which might have been affected by mineral water springs. This reserve was probably a remnant of the postglacial salty steppes, and during the following climatic-vegetation oscillations, the succession was ecologically blocked. Habitats were very labile and sensitive towards extrenal interventions. Usually, changes in water regime (drying, draining, and melioration) led to release and its extinction.

Research on recent flora proved that there was vegetation from salty meadows, communities from saline soils on the banks of ponds and temporary pools, meadow vegetation on waterlogged soils and therophytes from strongly saline and nitrogen rich bank edges of brackish water lakes. There may also have existed various reed swamps. Some of them are even considered as endemites of the Pannonian lowland (Vicherek 1973).

\section{Palaeoalgological research}

Palaeoalgological research on the Čejčské Lake sediments aided resolution of some debatable stratigraphic points which could not be decided based on only terrestrial vegetation development. The algal flora was not very rich because of poor preservation of some types of Pediastrum (P. boryanum, P. boryanum var. boryanum, see Fig. 7) and Botryococcus (B. braunii, B. braunii-type, B. neglectus, B. neglectus-type, B. neglectus/pila, see Fig. 8) mostly as a consequence of specifically deposited sediment and the brackish water in the lake.

The Čejčské Lake itself is considered as the lake with the highest salinity in our territory. It is not a residue of a former sea, but its salinity was caused by the Tertiary sediments and also probably by oscillation of its level and climatic conditions during its development in the Quaternary.

Layer between 1.45-2 m:

CEJ-1a-Ia: Pinus - P. cembra

CEJ-1b-Ib: Pinus - P. cembra - Chenopodiaceae

CEJ-1c-Ic: Pinus

CEJ-2-II: Pinus - Betula-Populus - Potamogeton-Abies

CEJ-3-III: Pinus

As far as the algal spectrum is concerned, the green chlorococal algae of Botryococcus prevails accompanied by sporadic occurrence of Pediastrum algae ( $P$. sp., $P$. boryanum, $P$. $b$. var. boryanum, $P$. angulosum var. asperum, $P$. duplex var. rugulosum) and other types of Tetraedron, Mougeotia and Spirogyra in sharp contrast for example, with the Vacenovice Lake. The ample occurrence of Botryococcus with the absence or only sporadic incidence of other green chloroccocal algae, probably indicates specific conditions in the water reservoirs, and dominates in the relatively extreme natural environment which prevents the presence of, for example, Pediastrum (Břízová 1991a, b, 1996 - the Černé Lake; Jankovská \& Komárek 2000; Komárek \& Jankovská 2001). However, in two cases in this study, at the depths of 1.45 and $1.3 \mathrm{~m}$ a high concentration of Botryococcus and Pediastrum was found. Both indicate very cold, clean water, oligotrophic or dystrophic, partly characteristic of cold periods and higher altitudes according to the so far conducted research (Jankovská \& Komárek 2000). In this area of southern Moravia, the condition of mountainous climate cannot be applied, but it is partly substituted for by the cold climate of the Late Glacial. As a suggestion, the algal incidences might be compared with some conditions in the Černé Lake in the Šumava Mts (Břízová 1996), where only Botryococcus was found. A more detailed determination of this genus was not carried out, but it was stated that several types occur here probably B. neglectus, B. pila, B. braunii. In the algal spectrum in Moravia, some types occur indicating somewhat climaticly more demanding conditions and water of rather eutrophic character. It is either another further proof of re-deposition or alternatively of the onset of warmer periods of the Holocene. Similar to re-deposition of representatives of macro-vegetation, various types of Pediastrum (see above) also sporadically occur in the algal assemblages. These types might prove, in combination with other types of algae, such as Tetraedron, Spirogyra, Mougeotia and Botryococcus, the presence of perhaps more eutrophic water in the lake, which markedly warmed up but not until the following period, even though the terrestrial vegetation indicates rather colder conditions. However, both the vegetation and geological hiatus in sedimentation was corroborated and supports the correctness of such an assumption. The conclusions of the palaeoalgological study correspond with the results of the pollen analysis.

Layer between 1.2-1.45 m:

CEJ-4-IV-V: Pinus - Betula - Artemisia

Palaeoalgological findings are mainly confined to Pediastrum, however, mostly as a consequence of poor preservation, type is indeterminable $P$. boryanum, $P$. b. var. boryanum and

Figure 8. Algae from the Čejčské Lake ČEJ 27. • A, B - Mougeotia, sample 39, depth 1.95 m. • C-E - Botryococcus braunii-type, sample 39 , depth 1.95 m. - F-Botryococcus neglectus-type, sample 38, depth $1.9 \mathrm{~m} \cdot \bullet \mathrm{G}, \mathrm{H}-$ Botryococcus braunii, sample $4-2$, depth $0.2 \mathrm{~m}$. $\bullet$ I, J - Botryococcus braunii-type, sample 39, depth $1.95 \mathrm{~m}$. $\bullet \mathrm{K}$ - Botryococcus braunii, sample 38, depth $1.90 \mathrm{~m}$. $\bullet \mathrm{L}-$ Botryococcus neglectus/pila, sample 39 , depth $1.95 \mathrm{~m}$. $\bullet \mathrm{M}-$ Botryococcus braunii-type, sample 39, depth 1.95 m. • N, O - Botryococcus neglectus, sample 39, depth 1.95 m. Photo E. Bř́zová. Determination by V. Jankovská. 
Eva Břizová • Quaternary environmental history of the Čejčské Lake (Moravia)
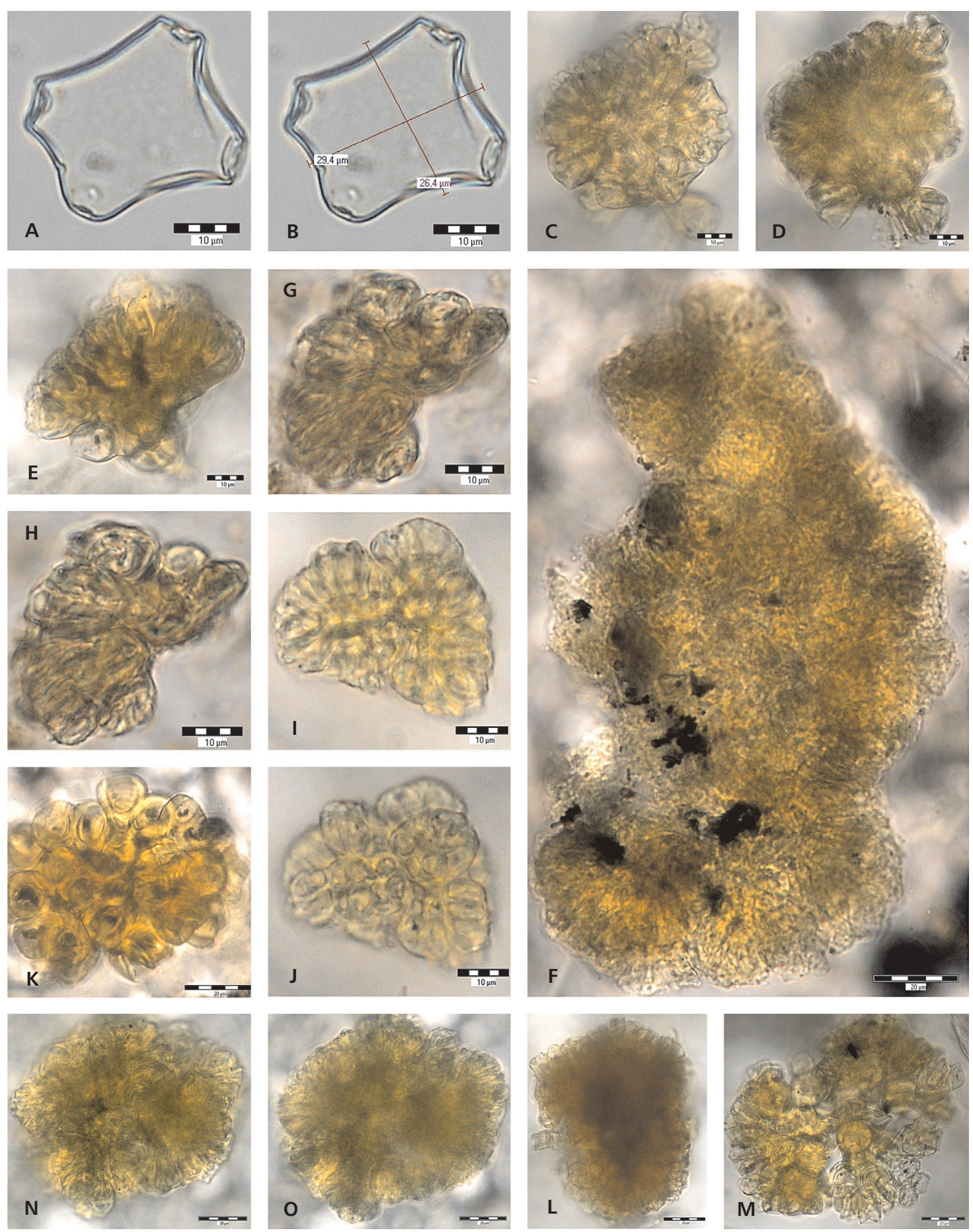
var. longicorne only were determined in detail. Apart from the depth of $1.3 \mathrm{~m}$, the number of algal colonies of Botryococcus markedly decreased. A qualitatively higher variability of algae and an ample quantitative incidence is rather characteristic of lakes in Central Europe from the Middle and Lower Holocene (Jankovská \& Komárek 2000, Komárek \& Jankovská 2001). This does not quite correspond to conditions in the Čejčské Lake. Nevertheless, it was a guideline for the stratigraphic specification of this layer. The presence of water macro-vegetation (types of Myriophyllum and Potamogeton) and other wetland types of Typha latifolia, T. angustifolia/Sparganium, again confirm the previous conclusions.

Layer between 0.9-1.2 m:

CEJ-5-VIII: Picea - Pinus - Asteraceae Liguliflorae -

Chenopodiaceae - Cyperaceae - Helianthemum

The Subboreal period (VIII) is commonly characterized by a drier, colder climate than the climatic optimum of the Atlantic. A considerable decline in the algal component, which in the present study is represented mostly by Botryococcus and poorly preserved types of Pediastrum, is also corroborated here. In this period the lake probably recieved a greater supply of salt originating from Neogene sediments, which is also proved by a massive increase of terrestrial halophytes (Chenopodiaceae, Asteraceae).

Layer between $0.7-0.9 \mathrm{~m}$ :

CEJ-6-IX: Pinus - Alnus - Cyperaceae-Chenopodiaceae

The same situation regarding the algal flora was also recorded in this bed which crosses into the Older Subatlantic (IX). In the previous bed (VIII), as well as in this one, the smallest representation of algal flora was recorded.

Layer between 0-0.7 $\mathrm{m}$ :

CEJ-7a-Xa: Chenopodiaceae - Pinus - Quercus - Cerealia CEJ-7b-Xb: Chenopodiaceae - Pinus - Asteraceae Brassicaceae

In the older phase of the Younger Subatlantic there was a slight increase in Botryococcus algae. Otherwise, there are only sporadic findings of algae, for example, Mougeotia.

\section{Stratigraphy}

Although the whole thickness of sediments sampled from the borehole ČEJ 27 is only $2 \mathrm{~m}$, from the palynological and palaeoalgological point of view, considerable complexity in stratigraphic development could be suggested. The proposed situation is recorded in details in Table 1 and the pollen diagram (Figs 4-8). The time classification of sediments and geological conditions are briefly described in the following overview:

Quaternary

0-0.7 m: medium brown-black, humous loam Younger Subatlantic age: younger phase $\mathrm{Xb}$ (1,200 y. AD-recent); older phase Xa (500/650/700-1,200 y. AD)

0.7-0.9 m: black strongly humous loan with peat residues Older Subatlantic IX age $(2,800 / 2,300$ B.P. to 500/650/700 y. AD)

0.9-1.2 m: grey-brown, strongly clayey loam Subboreal VIII age (5,100-2,800/2,300 B.P.)

1.2-1.4 m: white, clayey horizon, strongly enriched with $\mathrm{CaCO}_{3}$ (hiatus)

Preboreal age (IV, 10,250-9,100 B.P.) to onset of Boreal (V, 9,100-7,700 B.P.)

The hiatus - climatic optimum of the Holocene - Atlantic (VI, VII, 7,700-5,100 B.P.)

1.4-2 m: green-grey and yellow-rusty, streaky and spotted clay $\left({ }^{14}\right.$ C: $9,990 \pm 275$ B.P., Hv-18 924)

The age is indeterminable more precisely, the Late Glacial (15,000/13,000-10,250 B.P.) and the Early Holocene development of vegetation was affected by redeposition from the Tertiary, Middle Holocene and probably also Pleistocene strata.

Tertiary

2-6 m: steel-grey clay, at the depth of 4-6 m thinly stratified, with brown positions (re-deposited?).

\section{Conclusion}

The biostratigraphical research on Quaternary sediments from the Čejčské Lake (Figs 1-4) showed the considerable complexity of sediment development and their stratigraphical classification. The vegetation and algal flora listed in detail in Table 1 and including the pollen diagram (Fig. 4, photos: Figs 5-8) confirm this observation. The age classification of sediments, clarification of geological and vegetation conditions are summarized in this paper. The aim of this study was to reconstruct the vegetation history, stratigraphical position of the sediments (for geological mapping) and determine the natural and anthropogenic influences on this area. The Tertiary age of sediments under the Quaternary sediments was suggested and verified from the borehole ČEJ 27, from 2 (2.2) m to $30 \mathrm{~m}$ (Čtyroký et al. 1990). 


\section{Acknowledgments}

The submitted work originated within the geological mapping of sheet 1: 25000 34-214 Čejkovice, and for the state administration in Hodonín. The project formed part of the complex research program of the Czech Geological Survey Prague (Ministry of the Environment research project MZP 0002579801 and the Ministry of the Environment - Global Climatic Changes research program). My sincere gratitude goes to P. Havlíček for providing sediments from the borehole ČEJ 27 and for advice on various geological problems and also to V. Jankovská for her invaluable help in determination of algal flora.

\section{References}

BŘízOVÁ, E. 1991a. Výsledky palynologického výzkumu v roce 1989. Zprávy o geologických výzkumech v roce 1989, 27-29.

BŘízovÁ, E. 1991b. Výsledky pylových analýz v roce 1990. Zprávy o geologických výzkumech v roce 1990, 20-21.

BŘízOVÁ, E. 1993. The importance of pollen analysis for the reconstruction of vegetation development during the last two millenia, 22-29. In RŮŽIČKOVÁ, E., ZEMAN, A. \& MIRECKI, J. (eds) Application of direct and indirect data for the reconstruction of climate during the last two millenia. Papers presented at the workshop of PAGES - Stream I held in Brno, June 1992.

BŘízOVÁ, E. 1994. Vegetation of the Holsteinian interglacial in Stonava-Horní Suchá (Ostrava region). Sborník geologických věd, Antropozoikum 21, 29-56.

BŘízOVÁ, E. 1995. Postglacial development of vegetation in the Labe river valley course, 111-118. In RƯŽIČKOVÁ, E. \& ZEMAN, A. (eds) Manifestation of climate on the earth's surface at the end of Holocene. PAGES - Stream I.

BŘízOVÁ, E. 1996. Palynological research in the Šumava Mountains (Palynologický výzkum Šumavy). Silva Gabreta 1, 109-113.

BŘízOVÁ, E. 1999. Sedimenty ledovcových jezer Šumavy a Krkonoš (pylová analýza) [Sediments of the glacial lakes of the Šumava and Krkonoše Mts. (pollen analysis)]. Zprávy o geologických výzkumech $v$ roce 1998, 128-129.

BŘízOVÁ, E. 2000. Palynologický a paleoalgologický výzkum př́irodní památky Jezero. MS ČGS Praha, Geofond, OkÚ Hodonín. [in Czech]

BŘízOVÁ, E. 2001a. Palynologický a paleoalgologický výzkum přírodní památky Jezero u Vacenovic v okrese Hodonín (Palynological and palaeoalgological study of the Jezero Nature Monument near Vacenovice, district Hodonín). Příroda 19, 131-144.

BŘíZOVÁ, E. 2001b. Palynologické vyhodnocení vrtu Čej 27 v hloubkovém intervalu 1-2 m. 35 pp. MS C̆GS Praha, Geofond Praha. [in Czech]

BŘízOVÁ, E. 2006. Palaeoalgology and palynology of the Vacenovice Lake. Acta Universitatis Carolinae, Geologica 47(1-4), 41-42.

BŘízOVÁ, E. 2008. Palaeogeoecological research of the sediments in a former lake Stará jímka (Bohemian/Bavarian Forest), 14-16. In PiSERA, A., BITNER, M.A. \& HALAMSKI, A.T. (eds) $9^{\text {th }}$ Paleontological Conference Warszawa, 10-11 October 2008. Warszawska Drukarnia Naukowa PAN, Warszawa.
BŘíZOVÁ, E. \& HAVLÍČEK, P. 1999. Výzkum organických sedimentů na listech Kyjov a Vracov (Investigation of the organic sediments on the sheets Kyjov and Vracov). Zprávy o geologických výzkumech v roce 1998, 11-12.

BŘízovÁ, E., HavlíčeK, P., NovÁK, Z. \& Petrová, P. 2000. Kvartérní sedimenty na listu Vracov 34-222 a Strážnice 34-223 (Quaternary sediments on streets Vracov 34-222 and Strážnice 34-223). Zprávy o geologických výzkumech v roce 1999, 14-17.

BŘízOVÁ, E., HAVLíčEK, P. \& VACHEK, M. 2001a. Přírodní památka Jezero - palynologický a paleoalgologický výzkum (The protected locality Jezero - palynological and palaeoalgological research). Zprávy o geologických výzkumech v roce 2000, 64-66.

BŘíZOVÁ, E., HAVLíčEK, P. \& VACHEK, M. 2001b. Výzkum organických sedimentů na jižní Moravě (Research of the sediments in the South Moravia). Zprávy o geologických výzkumech $v$ roce 2000, 67-69.

BŘíZOVÁ, E., HAVLÍČEK, P. \& MENTLÍK, P. 2006. Geologický, geomorfologický a paleoekologický výzkum sedimentů v okolí Srní (Geological, geomorphological and palaeoecological research of the sediments in the Srní area). Zprávy o geologických výzkumech v roce 2005, 61-64.

BŘízovÁ, E., MENTLíK, P. \& PAZDUR, A. 2007a. Palaeoecological, geological and geomorphological research of the sediments in a former lake Stará jímka (Bohemian/Bavarian Forest), 102-103. In MOGILEWSKI, P., WYSOTA, W. \& WECKWERTH, P. (eds) Plejstocen Kujaw i dynamika lobu Wisty w czasie ostatniego zlodowacenia - XIV Konferencja "Stratygrafia plejstocenu Polski”. Uniwersytet Mikołaja Kopernika Uniwersitet Łodzki, Państwowy Instytut Geologiczny, Komitet Badań Czwartorzędu Polskiej Akademii Nauk, Warszawa.

BŘíZOVÁ, E. \& PAZDUR, A. 2007b. Změny přírodního prostředí ve Staré jímce (rašeliniště - jezero) v průběhu posledních 15000 let, 39-43. In DVOŘÁK, L., ŠUSTR, P. \& BRAUN, V. (eds) Aktuality šumavského výzkumu III. Správa NP a CHKO Šumava, Vimperk.

BŘízovÁ, E., HAVlíčEK, P., NovÁK, Z. \& PetrovÁ, P. 2000. Kvartérní sedimenty na listu Vracov 34-222 a Strážnice 34-223 (Quaternary sediments on streets Vracov 34-222 and Strážnice). Zprávy o geologických výzkumech v roce 1999, 14-17.

BŘíZOVÁ, E., HAVLÍčEK, P. \& VACHEK, M. 2001a. Přírodní památka Jezero - palynologický a paleoalgologický výzkum (The protected locality Jezero - palynological and palaeoalgological research). Zprávy o geologických výzkumech v roce 2000, 64-66.

BŘíZOVÁ, E., HAVlíčEK, P. \& VACHeK, M. 2001b. Výzkum organických sedimentů na jižní Moravě (Research of the sediments in the South Moravia). Zprávy o geologických výzkumech v roce 2000, 67-69.

ČTYROKÝ, P. ed. 1990. Vysvětlivky k základní geologické mapě 1 : 25000 34-214 Čejkovice. Český geologický ústav, Praha. [in Czech]

DOHNAL, Z., KUnST, M., MEJSTříK, V., RAUČInA, Š. \& VYDRA, V. 1965. Československá rašeliniště a slatiniště. 336 pp. ČSAV, Praha. [in Czech]

Dreslerová, D., BŘízová, E., RƯŽIČKovÁ, E. \& ZEMAN, A. 2004. Holocene environmental processes and alluvial archaeology in the middle Labe (Elbe) valley, 121-171. In GoJDA, M. (ed.) Ancient landscape, settlement dynamics and non-destructive archaeology. Academia, Praha. 
ERDTMAN, G. 1943. An introduction to pollen analysis. 712 pp. Academic Press, New York.

ERDTMAN, G. 1954. An introduction to pollen analysis. 238 pp. Chronica Botanica, Waltham, Mass.

FIRBAS, F. 1949, 1952. Spät- und nacheiszeitliche Waldgeschichte Mitteleuropas nördlich der Alpen. I - 480 pp., II - 256 pp. G. Fischer, Jena.

GRULICH, V. 1987. Slanomilné rostliny na jižní Moravě. Katalog historických lokalit jihomoravských lokalit. 76 pp. ČSOP, Břeclav. [in Czech]

HAVLÍČEK, P. \& ZEMAN, A. 1979. Kvartérní poměry mezi Kobylím, Brumovicemi a Čejčí na jihovýchodní Moravě. Sborník geologických věd, Antropozoikum 12, 31-55.

HRUŠKA, J., ChARLES, D.L., BŘíZOVÁ, E. \& VeselÝ, J. 2000. How much acidification has occurred in Prášilské lake since preindustrial times?, p. 21. In The International workshop Acidified Lakes in the Bohemian/Bavarian Forest - History, Present and Future, March 21-23, 2000. České Budějovice, Czech Republic.

HRUŠKA, J., CHARLES, D.F., BŘÍZOVÁ, E., VESElÝ, J., NOVÁK, M. \& KOPÁČEK, J. 1999. Paleolimnologická rekonstrukce preindustriálních acidobazických vlastností povrchových vod postižených antropogenní acidifikací. MS Závěrečná zpráva grantového projektu GAČR 205/96/0933, Archiv ČGS Praha. [in Czech]

HRUŠKA, J. \& BŘíZOVÁ, E. 2007. Wielki Staw a historie přírodních poměrů Krkonoš, 166-168. In FLOUSEK, J., HARTMANOVÁ, O., ŠTURSA, J. \& POTOCKI, J. (eds) Krkonoše: př́roda, historie, život. BASET, Praha.

JANKOVSKÁ, V. 1983. Palynologische Forschung am ehemaligen Komořany-See (Spätglazial bis Subatlantikum). Věstník Ústředního ústavu geologického 58(2), 99-107.

JANKOVSKÁ, V. 1988. Palynologische Erforschung archäologischer Proben aus Komořanské jezero-See bei Most (NW-Böhmen). Folia geobotanica et phytotaxonomica 23, 45-77.

JANKOVSKÁ, V. 2000. Komořanské jezero Lake (CZ, NW Bohemia) - A unique natural archive. Geolines 11, 115-117.

JANKOVSKÁ, V. 2006. Late Glacial and Holocene history of Plešné Lake and its surrounding landscape based on pollen and palaeoalgological analyses. Biologia 61(20), 371-385. DOI 10.2478/s11756-007-0064-x

JANKOVSKÁ, V. 2007. Giant Mountains and pollenanalytical research: New results and interesting palaeobotanical findings. In ŠTURSA, J. \& KNAPIK, J. (eds) Geoekologické problémy Krkonoš, Sborník Mezinárodní vědecké konference, řijen 2006. Opera Corcontica 44(1), 227-242.

JANKOVSKÁ, V. \& KOMÁREK, J. 2000. Indicative value of Pediastrum and other coccal green algae in palaeoecology. Folia geobotanica et phytotaxonomica 35, 59-82.

\section{DOI 10.1007/BF02803087}

KOMÁREK, J. \& JANKOVSKÁ, V. 2001. Review of the green algal genus Pediastrum; Implication for pollen-analytical research. Bibliotheca Phycologica 108, 1-127.

KovANDA, J. 1956. Předběžná zpráva o výzkumu sladkovodní křídy u Měňan. Anthropozoikum 5, 401-405.

KovandA, J. 1971. Kvartérní vápence Československa. Sborník geologických věd, Antropozoikum 7, 1-237.

KNEBLOVÁ, V. 1958a. Interglaciální flóra na Ostravsku. Věstník Ústředního ústavu geologického 33, 293-296.
KNEBLOVÁ, V. 1958b. Paleobotanické zpracování interglaciálních sedimentů v oblasti Suchá-Stonava. MS Ústřední ústav geologický, Praha. [in Czech]

KNEBLOVÁ-VODIČKOVÁ, V. 1961. Entwicklung der Vegetation in Elster-Saale Interglazial im Suchá - Stonava Gebiet (Ostrava Gebiet). Anthropozoikum 9, 129-174.

LOŽEK, V. 1973. Př́roda ve čtvrtohorách. 372 pp. Academia, Praha.

Macoun, J., ŠIBRAVA, V., TYRÁČEK, J. \& KNEBlovÁ-VodiČKOVÁ, V. 1965. Kvartér Ostravska a Moravské brány. 419 pp. Ústřední ústav geologický, Praha.

MANGerud, J., ANDERSEN, S.T., BERgLund, B.E. \& DONNER, J. 1974. Quaternary stratigraphy of Norden, a proposal for terminology and classification. Boreas 3, 109-128.

PELíšEK, J. 1951. Solné výkvěty na půdách jižní Moravy. Př́roda 44, 153-158.

PÍCHA, F., HANZLíKOVÁ, E. \& CiCHA, I. 1968. Geologie čejčsko-zaječské zóny. Sborník geologických věd, Řada G-Geologie 13, 37-74.

RYBNÍČEK, K. 1983. The environmental evolution and infilling process of a former lake near Vracov (Czechoslovakia). Hydrobiologia 103, 247-250. DOI 10.1007/BF00028460

RYBNÍČEK, K. ed. 1989. Excursion guide book, 83-84. The XII ${ }^{\text {th }}$ International meeting of European Quaternary botanists, June $5^{\text {th }}-15^{\text {th }}$. Brno.

RYBNÍČKOVÁ, E. 1985. Dřeviny a vegetace Československa v nejmladším kvartéru. Ph.D. thesis, Masaryk University, Brno. MS Botanický ústav AV ČR Průhonice. [in Czech]

RYBNÍČKOVÁ, E. \& RYBNíČEK, K. 1972. Erste Ergebnisse paläogeobotanischer Untersuchungen des Moores bei Vracov, Südmähren. Folia geobotanica et phytotaxonomica 7, 285-308.

ŘEHÁKOVÁ, Z. 1988. Biostratigraphy and palaeoecology of Diatom-bearing sediments within the Soos basin in western Bohemia, Czechoslovakia. 10 Diatom-Symposium 1988, 407-418.

SvobodOVÁ, H. 1989. Svatobořice-Mistřín, 84-85. In RYBNÍČEK, K. (ed.) Excursion guide book. The XII International meeting of European Quaternary botanists, June $5^{\text {th }}-15^{\text {th }}$, Brno.

SvobodovÁ, H. 1997. Die Entwicklung der Vegetation in Südmähren (Tschechien) während des Spätglazials und Holozäns eine palynologische Studie (Development of the vegetation in South Moravia /Czech Republic/ during the Late Glacial and Holocene - a palynological study). Verhandlungen der Zoologisch-Botanischen Gesellschaft in Österreich 134, 317-356.

SÝKORA, L. 1959. Rostliny v geologickém výzkumu. 322 pp. ČSAV, Praha.

SYMONOVÁ, R. 2002. Předběžná zpráva o výzkumu ostrakodové fauny Čejčského jezera (Preliminary report on research of ostracods fauna of the Čejč Lake). Zprávy o geologických výzkumech v roce 2001, 109-110.

Šumberová, K., LososovÁ, Z. \& ŠMARdA, P. 2004. Nové nálezy Veronica scardica na jižní Moravě (New finds of Veronica scardica in South Moravia). Zprávy České botanické společnosti 39, 161-166.

VICHEREK, J. 1973. Die Pflanzengesellschaften der Halophytenund Subhalophytenvegetation der Tschechoslowakei. 200 pp. Academia, Praha.

WALANUS, A. \& NALEPKA, D. 1999. POLPAL. Program for counting pollen grains, diagrams plotting and numerical analysis. Acta Paleobotanica, Supplement 2, 659-661. 